\title{
Customer Spending in the Egyptian Hotels After the Exchange Rate Liberalization
}

Ahmed Rady, Moamen Abou Elezz, Mahmoud Abdel-Aziz*

Faculty of Tourism and Hotels, Minia University, Egypt.

ARTICLE INFO

Keywords:

Exchange Rate

Liberalization

Hospitality

Customer Spending

Economic Factors

Price

Length of stay

\begin{abstract}
The exchange rate liberalization greatly affects the Egyptian tourism industry, customer spending is the main driving element that continues to encourage tourism expansion since it is considered a tool for economic growth, and it is essential to understand the customer spending. The purpose of the research is to study the impact of exchange rate liberalization on customer spending in Egyptian hotels. A mixed technique (quantitative and qualitative) is used to achieve the research objectives. To collect data, a questionnaire targeted Egyptian and foreign tourists, and interviews conducted with hotel managers and tourism experts in the four tourist cities, Hurghada, Marsa Alam, Safaga, and Luxor were employed from March to May 2021 (the months when the field work was applied).The research results found that there is an increase in the value of the Egyptian pound and the level of spending has been severely impacted due to high costs and the price of products. There is a statistically significant effect of the exchange rate liberalization on the customer spending of Egyptian guests in hotels, as there is a negative impact that has led to a decrease in the level of spending of Egyptian tourists because of the depreciation of the Egyptian pound against the dollar.
\end{abstract}

(C2021 Faculty of Tourism and Hotels, Fayoum University All rights reserved

\section{Introduction}

Tourism has a great role in the Egyptian economy by generating employment and contributing to national income (Aalen et al., 2019). Therefore, the hospitality industry is considered as a significant branch that influences the country's economic development by providing a variety of services for people who are away from homes, such as lodging, food, and beverages, as well as bringing a high level of income to the country (Njoya, 2020). Moreover, the exchange rate mechanism is one of the most important tools of economic policy and is considered the central element in the financial economy of many countries around the world, also the exchange rate is the difference between the parity rates between the two currencies (Anter and El-Nagy, 2018). During the last two decades, many small open economies have officially abandoned their fixed exchange rate arrangements to allow their currencies to float (Alstadheim et al., 2021). These fluctuations in currency rate and the economic state are the most significant variables impacting the hotel industry when the country's currency depreciates, inbound tourism becomes less expensive resulting in a rise in tourism flows

\footnotetext{
*Contact Mahmoud Abdel-Aziz at: Mahmoud.abdel-aziz@mu.edu.eg
} 
to that country (El-Gazar, 2018). On the other hand, the liberalization of the exchange rate led to an increase in the dollar price against the Egyptian pound, additionally, affected the prices of goods, services, and tourism products (Anter and El-Nagy, 2018). As a result, it has been noticed that the liberalization of the exchange rate has influenced the occupancy rate and spending rate due to price increases (Soliman and Shaded, 2018). Furthermore, there is a shortage of research that deals with the impact of the liberalization of the currency rate on the customer spending in hotels. The purpose of the research is to study the impact of exchange rate liberalization on customer spending in Egyptian hotels.

\section{Literature review}

\subsection{Exchange Rate Definition}

According to the International Monetary Fund, the exchange rate is the difference between the prices of two international currencies, and it is defined as "the relationship between two currencies linked or the value of one currency for conversion to another," so it is a key to determining the relationship between local and international prices (IMF, 2018; Ezzahid and Maouhoub, 2020). The exchange rate, which determines the value of one currency against another (foreign currency against domestic currency), reflects a country's ability to compete in global markets (He et al., 2021).

\subsection{The Reasons that Led to Liberalize the Exchange Rate}

El-Gazar (2018) and Amador et al. (2020) stated that implementing flexible exchange rates serves three purposes: first, to reduce inflation through consumption and improve exports; second, to ensure political stability; and third, to control the impact of major global currency fluctuations. Moreover, El-Sherbini (2018) pointed out that there are a variety of causes behind Egypt's recurrent hikes in the dollar exchange rate. First, the intention is to close the difference between the official rate and the parallel market price by unifying the two rates to abolish the black market. Second, the central bank's recent move to lower interest rates on bank deposits. Three, the aid of the International Monetary Fund may have been one of the most important factors, which allowed them to pay off their debts. As well as to reduce the budget deficit and public debt, complete the support system reform, increase exports, encourage domestic and foreign investment, and reduce imports (Soliman and Shedeed, 2018). On the other hand, Inflation, interest rates, capital account balances, speculators, manufacturing costs, country debt, GDP, political stability and economic performance, employment data and rate, purchasing power parity, the relative strength of other currencies, and monetary policy are all influences on the exchange rate (Amador et al., 2020; Yu, 2021; Yung, 2021).

\subsection{Exchange Rate Liberalization Action Plans in Egypt}

Egypt has witnessed successive cycles of progress in the mechanisms of the exchange rate, the exchange rate arrangements in Egypt ranged between the managed exchange rate system, the exchange rate pegged to the dollar, and the crawling peg exchange rate in the face of a complex basket of currencies and stabilized until the end of the announcement of the full floating of the Egyptian pound on the third of November 2016 (El-Sherbini, 2018). At the end of June 2003, the liberalization of the exchange rate decreased the Egyptian pound value by $23.3 \%$, and the weighted average price of the dollar was 6.032 pounds, compared to 4.626 pounds at the end of June 2002, with a continuing gap between the exchange rate inside banks on the black market at the second half of 2004 (CBE, 2003; IMF, 2005). Also, ElSherbini (2018) pointed out that these developments have resulted in the aforementioned balance of payments, which led to a continuous increase in the value of the Egyptian pound against the dollar from 2005 until the outbreak of the financial crisis during the financial year $2008 / 2009$, so that the decline in its exchange rate against the dollar was limited to 5.71 EGP at the end of June 2010, compared to 5.35 EGP at the end of 2009 (CBE, 2010).Furthermore, Egypt perceived a frequency of supply shocks, which were represented by a decrease in the supply of goods and an increase in the prices of some goods and services determined administratively by the government, as well as the impact of the continuous deterioration in the value of the Egyptian pound, where the official exchange rate of the dollar rose from 7.63 pounds in June 2015 to 8.88 pounds in June 2016 (CBE, 2016).Therefore, on the third of November 2016, the Central Bank of Egypt announced that the Egyptian pound would float and reduce the support for petroleum products 
in implementing one of the most important requirements of the international monetary fund, this policy is classified as "free-floating" according to the supply and demand mechanisms (IMF, 2020; Abdelgany, 2020). These decisions have decreased the value of the Egyptian pound and the exchange rate of the dollar jumped and resulted in an increase in the prices of petroleum products $(\mathrm{CBE}$, 2020).

Table 1

The Average Currencies Exchange Rates in Egyptian pound (2016-2020)

\begin{tabular}{|l|l|l|l|l|l|l|l|l|}
\hline \multirow{2}{*}{ End of } & \multicolumn{2}{|c|}{ Dollar } & \multicolumn{2}{c|}{ Euro } & \multicolumn{2}{c|}{ Strl. Pound } & \multicolumn{2}{c|}{ Chin. Yuan } \\
\cline { 2 - 9 } & Buy & Sell & Buy & Sell & Buy & Sell & Buy & Sell \\
\hline $\mathbf{2 0 1 6}$ & 8.85 & 8.88 & 9.81 & 9.84 & 11.8 & 11.9 & 1.33 & 1.33 \\
\hline $\mathbf{2 0 1 7}$ & 18.0 & 18.1 & 20.4 & 20.5 & 23.1 & 23.2 & 2.65 & 2.66 \\
\hline $\mathbf{2 0 1 8}$ & 17.8 & 17.9 & 20.6 & 20.7 & 23.3 & 23.4 & 2.69 & 2.70 \\
\hline $\mathbf{2 0 1 9}$ & 16.6 & 16.7 & 18.9 & 19.0 & 21.1 & 21.2 & 2.42 & 2.43 \\
\hline $\mathbf{2 0 2 0}$ & 15.6 & 15.7 & 19.2 & 19.3 & 21.1 & 21.2 & 2.52 & 2.72 \\
\hline
\end{tabular}

Source: Central Bank of Egypt Annual Report (2016:2020)

According to the Central Bank of Egypt's annual reports on the exchange rate of the Egyptian pound against other currencies from 2016 to 2020, the liberalization of the Egyptian pound's exchange rate resulted in a decrease in the Egyptian pound's value when compared to other currencies. Where the exchange rate of the US dollar increased from 8,857 pounds during the year 2016 to 15,684 pounds at the end of the fiscal year 2019/2020 (table 1).

\subsection{The Effect of the Exchange Rate Liberalization on the Hospitality Industry in Egypt}

The exchange rate movements express an important determinant of tourism demand. As the movements of the exchange rate and the weakness of the economy were among the major factors affecting the hotel sector (Masoomzadeh and Lamsso, 2017). The reduction in the value of the national currency against foreign currencies and the increase in the exchange rate are factors affecting the balance of payments for tourism, at least in the short term, whereas the devaluation of a country's currency makes inbound international tourism less expensive (El-Sherbini, 2018). Furthermore, the depreciation of the Egyptian pound against the dollar has affected the prices of goods, services, and tourism products, as well as the international demand for tourism in Egypt, as the Egyptian tourist destination has become cheaper compared to other destinations (Anter and El-Nagy, 2018). Furthermore, the increase in the value of a country's currency made domestic tourism more expensive and led to a decrease in domestic tourism flows (El-Bagouri, 2016). On the other hand, the exchange rate has a little impact on the two sectors since the money generated by tourism and hotel services will be in dollars, increasing the value of revenues but increasing the cost of products and raw materials, which reflects a decrease in the purchasing power and increased commodity prices (Soliman and Shedeed, 2018).

\subsection{Customer Spending}

Customer spending is the main driving element that continues to encourage tourism expansion since it is considered a tool for economic growth (Park et al., 2020). Customers can be defined as persons who visit places and spend money based on their needs for housing, food, shopping, and transportation, which increases tourism revenues (Mokhtar and Shamsudin 2020). Several aspects that influence customer purchase decisions, including culture, subculture, social classes, group membership, family, psychology, age, income, marital status, and customer satisfaction, as well as external factors such as economic, political, and environmental factors, which have a direct impact on individual purchasing decisions (Andari et al., 2019).

\subsubsection{Internal Factors Affects Customer Spending}

Many internal factors influence tourist behavior in the hospitality sector, either directly or indirectly, influencing their purchasing decisions, which were categorized into four main categories: social and demographic characteristics related to the trip, and psychographic characteristics (Andari et al., 2019; Park et al., 2020).

\section{A. Demographic Factors}


There is a tension between the influences of demographic characteristics on customer spending in a tourist destination. Personal demographic factors such as age, gender, employment, income, and life cycle stage have a direct impact on the purchaser's decisions (Zhang et al., 2018). According to Luo (2019), age has a substantial influence on customer spending, which varies depending on the age of the tourists. As a result, according to Ramya and Ali (2016), the gender of customers influences on their buying power, while male visitors spending more than female visitors. Regarding the effects of marital status on customer spending, Luo (2019) concluded that there is no association between marital status and customer spending. However, Ramya and Ali (2016) discovered that single visitors spend more than married visitors. On the other hand, Income is the most significant economic factor influencing customer purchase behavior impact on customer lifestyle (Dorota, 2013). Furthermore, Luo (2019) and Ortega and Osbat (2020) discovered that when a customer's income rises, their desire for travel rises as well, and high-income customers spending more than low-income customers, which has a substantial influence on the product they purchase.

\section{B. Cultural and Social Factors}

According to Zhang et al. (2018) and Gavurova et al. (2020), culture is a crucial term in understanding customer behavior, and it is defined as the total of conventions, norms, traditions, and shared activities among members of society, all of which influence customer spending decisions. Subcultures such as nationality, as well as social class factors such as education and employment, have a direct influence on customer spending.

\subsubsection{External Factors Affects Customer Spending}

Customers in tourism destinations are influenced by a variety of elements connected to the surrounding environment, which naturally influence the tourist's purchase choice and have a direct impact on individual purchase decisions, such as economic, political, and environmental considerations (Ortega and Osbat, 2020; Hou and $\mathrm{Wu}, 2021)$.

\section{A. Economic Factors}

According to Hou and $\mathrm{Wu}$ (2021), the exchange rate has a significant influence on tourism, and the foreign currency rate has a significant influence on tourist spending at the tourist destination. Ortega and Osbat (2020) referred that there is a complex relationship between exchange rates and prices in the short, medium and long run, in addition to the strong association with the customer's decisionmaking process. Aditi (2019) stated that when the exchange rate falls, visitors' demand for services and other goods rises. Moreover, Mazzarol and Rebound (2020) explained that the price is the sum of money required to buy products and services in the tourism sector and is considered a critical predictor of customer spending and has an inverse connection with demand stability (when prices fall, demand rises).

According to statistics released by the Central Agency for Public Mobilization and Statistics (CAPMAS) and the Central Bank of Egypt between 2016 and 2019, the average spending of tourists per night increased to 86.0 US dollars in the fiscal year 2016/2017, up from 72.8 US dollars the previous fiscal year. In addition, the average visitor expenditure per night increased to 95.0 US dollars in the fiscal year 2017/2018 compared to the previous fiscal year figure1.

\section{Figure 1}

The average Tourist spending per Night in Egypt (20162019

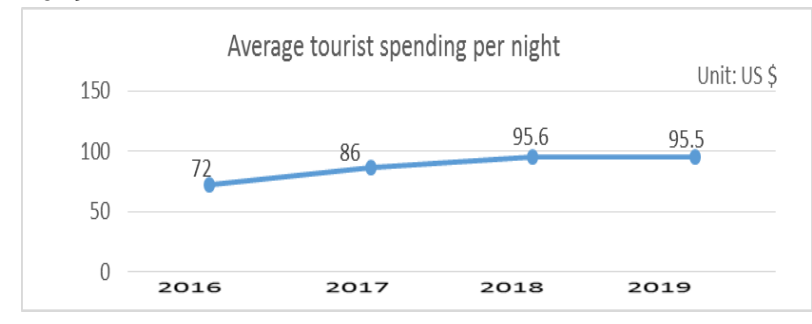

\section{B. Destination Related Factors}

Destination-related factors influence customers' spending on tourism destinations, such as travel activities, the purpose of visit, length of stay, firsttime/repeat visit, and type of accommodation (Putra, 2019). The large influence of customer spending on the length of stay at the place was discovered to have a beneficial influence on overall visitor expenditure (Park et al., 2020). In Australia and rural areas of Michigan, there is also a positive association between length of stay and customer spending (Solar et al., 2018). According to Gómez et al. (2019), a decline in vacationer expenditure accompanied the decrease in the vacation duration in Spain, discovered that the number of days spent on a trip had a negative influence on daily visitor expenditures, for example, a $1 \%$ increase in stay, results in a 0.31 percent increase in customer 
expenditure. Additionally, Anter and El-Nagy (2018) claimed that tourism costs are an explanatory variable for a tourist's destination because the Egyptian tourism destination became more cheaper due to the decrease in Egyptian pound and this made an increase in the international tourism and the Egyptian visitors who perceive a destination as luxurious spend more money than those who do not, and they can evaluate the current price of a product or service and compare it to a variety of prices in their memories

\section{Methodology}

The research relied on visitors who visit the tourist destination inside Egypt to provide data to measure the impact individually. A mixed technique was used to attain the research's goal (Quantitative and Qualitative). A quantitative technique based on a questionnaire was employed and targeted Egyptian and international visitors to the four tourist cities picked for the fieldwork application (Hurghada, Marsa Alam, Safaga, and Luxor), because they are among Egypt's most important tourist attractions and respectively because of their incredible natural, historical, and cultural values, they attract visitors from all over the world (Egyptian Tourism Authority, 2020) . Moreover, personal and telephone interviews were used as a qualitative method. Interviews were conducted with hotel managers, tourism experts in four major tourist locations. A quantitative method based on a questionnaire was prepared and distributed to a random sample of tourists from March to May 2021, to obtain the most information on the generalizability of study results, moreover, it is difficult in the social sciences to obtain data from every participant who is relevant to the study, but only from a small percentage of them (Khalaf et al.,2020). The questions are a mix of closed-ended and open-ended. The researchers devised the test problems and chose them after doing a literature study. The questionnaire comprised 15 questions divided into three sections. The first section contains personal information and travel arrangements (for example, country, age, gender, income categories, and educational level), as well as travel arrangements. There were eight statements about customer spending in section two. The third section comprised four statements in which the visitors were asked how long they planned to remain during their visit. On the other hand, interviews were used as a qualitative method, and 11 hotel managers and economists were interviewed in Egypt, they were called to determine the best time to schedule a personal interview at the workplace. The researchers also performed a personal interview over the phone. The interview consists of six carefully prepared questions. Respondents were asked to answer a series of openended questions. These comments helped collect data on the effects of exchange rate liberalization on Egypt's tourism economy, especially the hotel industry. This strategy was chosen because it allowed for clarifications and explanations.

\subsection{Research Hypothesis.}

H1: There is a positive relationship between the customer spending and the length of stay after the exchange rate liberalization.

$\mathrm{H} 2$ : There are no statistically significant differences between Egyptians and foreign tourists in terms of customer spending in hotels under the liberalization of the exchange rate.

H3: There are no statistically significant differences between males and females concerning customer spending in hotels under the liberalization of the exchange rate.

H4: There are no statistically significant differences between the age categories concerning customer spending in hotels under the liberalization of the exchange rate.

H5: There are no statistically significant differences between the income categories concerning customer spending in hotels under the liberalization of the exchange rate.

\subsection{The Research Sample}

The research was conducted on a random sample of Egyptian and foreign tourists in the Red Sea governorate cities of (Hurghada, Marsa Alam, and Safaga) and Luxor governorate from March to May 2021, because they are among Egypt's most important tourist attractions and respectively because of their incredible natural, historical, and cultural values, they attract visitors from all over the world (Egyptian Tourism Authority, 2020). To obtain the most information on the generalizability of study results, moreover, it is difficult in the social sciences to obtain data from every participant who is relevant to the study, but only from a small percentage of them (Khalaf et al., 2020). 
Table 2:

Number of Tourists in the Red Sea and Luxor Governorates in 2019.

\begin{tabular}{|l|l|l|l|}
\hline \multicolumn{1}{|c|}{ Tourists } & $\begin{array}{l}\text { Foreign } \\
\text { Tourists }\end{array}$ & $\begin{array}{l}\text { Egyptians } \\
\text { Tourists }\end{array}$ & Total \\
\hline $\begin{array}{l}\text { Revernorate } \\
\text { Governorate }\end{array}$ & 565255 & $43 \mathrm{q} 56845$ & 4922100 \\
\cline { 1 - 1 } $\begin{array}{l}\text { Luxor } \\
\text { Governorate }\end{array}$ & 68736 & 74082 & 142818 \\
\hline Total & 633991 & 4430927 & 5064918 \\
\hline
\end{tabular}

Source: Egyptian Tourism Authority (2020).

The sample size was calculated using the Stephen $\mathrm{K}$. Thompson equation, as follows: (Thompson, 2012)

$$
n=\frac{N \times p(1-p)}{\left.\left.\| N-1 \times\left(d^{2} \div z^{2}\right)\right]+p(1-p)\right]}
$$

where,

n: sample size (384), N: population size (5064918), $\mathrm{z}$ : confidence level at $95 \%$ (1.96), d: error proportion (0.05), b: probability $(50 \%)$.

\section{Table 3}

Nationality distribution according to sample size.

\begin{tabular}{|l|l|l|l|}
\hline Nationality & Foreign & Egyptians & Total \\
\hline Total & 633991 & 4430927 & $\mathrm{~N}=5064918$ \\
\hline$\%$ & $12.5 \%$ & $87.5 \%$ & $100 \%$ \\
\hline $\begin{array}{l}\text { Sample size } \\
\text { calculated }\end{array}$ & 48 & 336 & $\mathrm{n}=384$ \\
\hline
\end{tabular}

\subsection{Collecting Data}

The researchers distributed 678 forms to Egyptian tourists in two ways: 200 hard copies where 163 forms were valid to analyze out of this total (representing an 81.5 percent response rate), and the second option is to fill out an online questionnaire on Google Forms (https://forms.gle/oNKjVbzjKGkGHG3Y7), 478 people responded to this survey, there are 376 forms that are valid to be evaluated out of this total (representing a 78.8 percent response rate).The researchers distributed 408 forms to foreign tourist in two ways: 300 hard forms, there are 259 valid forms to analyze out of this total, reflecting an 86.3 percent response rate and the second method is to use an online questionnaire on Google Forms (https://forms.gle/VZbzKGaBWr79CXra9) to foreign tourists of various nationalities (Arab, Ukrainian, Romanian, Czech, and Belarusian), 108 Guests delivered it through an email address based on their reservation history in some hotels, here are 85 forms that are valid to be evaluated out of this total (representing a 78.7 percent response rate). From March to May 2021, these questionnaire forms were distributed during the last two days before the tourist's departure. The obtained data was processed and analyzed. This method included editing, coding the responses, grouping, tabulating the data, and doing statistical calculations such as frequencies, percentages, and other factors. Statistical procedures are followed, as well as the application of appropriate tests of significance, to ensure the formulation of conclusions collected through questionnaires. Closed-ended answers were analyzed by using the Statistical Package for the Social Sciences (SPSS) version 21, which computed frequencies, percentages, means, standard deviation, variance test, correlation between variables, the open-ended responses were examined qualitatively. Content analysis is one of the qualitative data analysis approaches that could be used in this study to analyze the data from the personal interviews in order to find characteristics of the data (Mishra and Alok, 2017). To examine the qualitative data gathered during the interviews, manual analysis procedures, according to the researcher, were more suited to testing and identifying relevant factors based on the responses of the respondents.

\section{Table 4}

Number of Questionnaire Forms and the Response Rate of the Tourists' Sample

\begin{tabular}{|l|l|l|l|}
\hline Nationalities & $\begin{array}{l}\text { Frequencies of } \\
\text { distribution } \\
\text { forms }\end{array}$ & $\begin{array}{l}\text { Frequencies } \\
\text { of Valid } \\
\text { forms }\end{array}$ & $\begin{array}{l}\text { Response } \\
\text { rate }\end{array}$ \\
\hline Egyptian & 678 & 539 & $79.4 \%$ \\
\hline Foreign & 408 & 344 & $84.3 \%$ \\
\hline Total & 1086 & 883 & $81.3 \%$ \\
\hline
\end{tabular}

\subsection{The Sample Characteristics}

The following table depicts the study's various factors using six elements: Nationality, Gender, Age group, Average income, Educational level, and marital status.

\section{Table 5}

Personal Data and Travel Arrangements

\begin{tabular}{|l|l|l|}
\hline Variable & Frequency & Percentage (\%) \\
\hline Egyptian & 539 & 61 \\
\hline Foreigners & 344 & 39 \\
\hline Total & 883 & 100 \\
\hline \multicolumn{3}{|c|}{ Nationality } \\
\hline Male & 441 & 49.9 \\
\hline Female & 442 & 50.1 \\
\hline
\end{tabular}




\begin{tabular}{|c|c|c|}
\hline Variable & Frequency & Percentage (\%) \\
\hline Total & 883 & 100 \\
\hline \multicolumn{3}{|c|}{ Age group } \\
\hline $\begin{array}{l}\text { Between 16: } 25 \\
\text { years old }\end{array}$ & 209 & 23.7 \\
\hline $\begin{array}{l}\text { Between 26: } 35 \\
\text { years old }\end{array}$ & 256 & 29.0 \\
\hline $\begin{array}{l}\text { Between } 36: 45 \\
\text { years old }\end{array}$ & 260 & 29.4 \\
\hline $\begin{array}{l}\text { More than } 46 \\
\text { years old }\end{array}$ & 158 & 17.9 \\
\hline Total & 883 & 100 \\
\hline \multicolumn{3}{|c|}{ Average Income } \\
\hline $\begin{array}{l}\text { Less than L.E } \\
4000\end{array}$ & 199 & 22.6 \\
\hline $\begin{array}{l}\text { From L.E 4001: } \\
\text { L.E } 8000\end{array}$ & 154 & 17.4 \\
\hline $\begin{array}{l}\text { From L.E } 8001 \\
\text { : L.E } 12000\end{array}$ & 221 & 25.0 \\
\hline $\begin{array}{l}\text { More Than L.E } \\
12000\end{array}$ & 309 & 35.0 \\
\hline Total & 883 & 100 \\
\hline \multicolumn{3}{|c|}{ Education level } \\
\hline $\begin{array}{l}\text { Middle } \\
\text { Certification }\end{array}$ & 90 & 10.2 \\
\hline $\begin{array}{l}\text { High } \\
\text { Qualification }\end{array}$ & 637 & 72.1 \\
\hline Master / PhD & 156 & 17.7 \\
\hline Total & 883 & 100 \\
\hline \multicolumn{3}{|c|}{ Marital Status } \\
\hline Single & 291 & 33.0 \\
\hline Married & 445 & 50.4 \\
\hline Divorced & 108 & 12.2 \\
\hline Widowed & 39 & 4.4 \\
\hline Total & 883 & 100 \\
\hline \multicolumn{3}{|c|}{$\begin{array}{l}\text { Did You Spend a Tourist Trip in Egypt after the } \\
\text { Liberalization of the Egyptian Pound Exchange } \\
\text { Rate? }\end{array}$} \\
\hline Yes & 883 & 100 \\
\hline No & 0 & 0 \\
\hline Total & 883 & 100 \\
\hline
\end{tabular}

Egypt after the Liberalization of the Egyptian Pound Exchange Rate. 100\% of the tourists spent a tourist trip in Egypt after the Liberalization of the Egyptian Pound Exchange Rate.

\section{Findings}

\subsection{Validity of the Research}

To improve the strength of the components, factor analysis was done with 1 as the Eigenvalue. The factorability tests indicate whether attempting to extract factors from a collection of variables is likely to be worthwhile (Hair et al., 2009).

Table 6

Component Matrix

\begin{tabular}{|l|l|}
\hline \multirow{2}{*}{} & Component \\
\cline { 2 - 2 } & 1 \\
\hline Length of stay & 0.969 \\
\hline Customer spending & 0.969 \\
\hline Extraction method: principal component analysis. \\
\hline \multicolumn{2}{|l|}{1 components extracted. } \\
\hline
\end{tabular}

The factors matrix, which comprises 2 factors, is shown in table (6). These variables show a correlation of better than 0.30 with two other variables, it can be deemed a good component to include.

Table 7

Correlation Matrix

\begin{tabular}{|l|l|l|l|}
\hline \multicolumn{2}{|c|}{} & $\begin{array}{l}\text { Customer } \\
\text { spending }\end{array}$ & $\begin{array}{l}\text { Length of } \\
\text { stay }\end{array}$ \\
\hline Correlation & $\begin{array}{l}\text { Customer } \\
\text { spending }\end{array}$ & 1.000 & 0.879 \\
\cline { 2 - 4 } & $\begin{array}{l}\text { Length of } \\
\text { stay }\end{array}$ & 0.879 & 1.000 \\
\hline
\end{tabular}

The Correlation Matrix of the internal variables in factor analysis was (0.879) shown in Table (7). When the correlation between the variables is over 0.30 , it is a strong indicator that the variables used in the assessment are of high quality.

\section{Table 8}

KMO and Bartlett's Test Egyptians (539), 39\% of the sample were foreigners. Most of the sample were males (441) whilst only $49.9 \%$, and 50.1 of the sample were females (442). Also, the age category of "36 to 45 years old" represents the highest percentage of the tourist sample (260) with $29.4 \%$. In terms of income, $35 \%$ of the sample earns more than 12000 pounds monthly (309). In terms of educational level, $72.1 \%$ of the sample is higher educated, and $50.4 \%$ of the sample is married. Also, the tourist sample was asked if they spent a tourist trip in

The results of the KMO measurement quality assurance test was shown in Table (8). The value of KMO is equal to.949, which according to Kaiser and Rice (1974) is a commendable level, and 
Bartlett's test for Sphericity was significant, $2=$ $10946, p=0.000$, showing that the measurement is outstanding (Rady et al., 2021).

\subsection{Reliability of the Research}

Cronbach's Alpha is computed to test the Reliability. Cronbach's alpha coefficient, which extends from 0 (no internal consistency) to 1 (perfect internal consistency), assesses this impact (maximum internal consistency). In most social science study contexts, a reliability coefficient of 0.70 or above is regarded as "acceptable" (Oluwatayo, 2012).

Table 9

Cronbach's Alpha value of the tourist's sample

\begin{tabular}{|l|l|l|l|}
\hline Variables & $\begin{array}{l}\text { No. of } \\
\text { items }\end{array}$ & $\begin{array}{l}\text { Cronbach's } \\
\text { Alpha value }\end{array}$ & $\begin{array}{l}\text { Validity } \\
\text { Coefficient* }\end{array}$ \\
\hline $\begin{array}{l}\text { Customer } \\
\text { spending }\end{array}$ & 8 & .956 & .978 \\
\hline $\begin{array}{l}\text { Length of } \\
\text { stay }\end{array}$ & 4 & .833 & .912 \\
\hline Total & 12 & .960 & .945 \\
\hline
\end{tabular}

* Validity coefficient $=\sqrt{ }$ Reliability coefficient

The reliabilities of the scales were assessed, and the Cronbach's Alpha values for all scales in Table (9) varied from 0.833 to 0.956 , with a total of 0.960 , showing an appropriate Cronbach's Alpha value for each field. It is also clear that the validity coefficient is (0.945), confirming the research sample's reliability and validity.

\subsection{Normality of Data Distribution}

Kolmogorov-Smirnova test was used to determine the normality of the distribution, which is a prerequisite for many statistical tests (Rady et al., 2021). The following table shows the results:

\section{Table 10}

Tests of normality

\begin{tabular}{|l|l|l|l|}
\hline \multirow{2}{*}{} & \multicolumn{3}{|c|}{ Kolmogorov-Smirnova } \\
\cline { 2 - 4 } & Statistic & df & Sig. \\
\hline Length of Stay & .134 & 883 & .000 \\
\hline Customer Spending & .121 & 883 & .000 \\
\hline a. Lilliefors Significance Correction \\
\hline
\end{tabular}

Table (10) confirms that the data distribution was non-normal for both items, with a Sig. value of less than 0.05 , meaning that the data for all study variables were non-normal (Rady et al., 2021). As a result, non-parametric tests such as MannWhitney, chi-square, and Kruskal-Wallis tests were used to assess the collected data to verify the study hypothesis's validity.

\section{Results and Discussion}

\section{Table 11}

Most preferred cities to stay in Egypt.

\begin{tabular}{|l|l|l|l|}
\hline Variable & Frequency* & Percentage (\%) & Rank \\
\hline Hurghada & 437 & 29.7 & 1 \\
\hline Marsa Alam & 409 & 27.8 & 2 \\
\hline Safaga & 271 & 18.4 & 4 \\
\hline Luxor & 353 & 24.1 & 3 \\
\hline
\end{tabular}

*More than one answer is possible.

Table (11) confirms that, in terms of cities that tourists preferred to stay in Egypt, "Hurghada" came in first rank (Frq. $=437, \mathrm{P}=29.7 \%$ ), followed by "Marsa Alam" (Frq. $=409, \mathrm{P}=27.8 \%$ ) and "Luxor" (Frq. = 353, P= 24.1\%). "Safaga" (Frq. = $271, \mathrm{P}=18.4 \%$ ) ranked the last variable. This result reflected the importance of Hurghada, Marsa Alam, and Luxor in attracting tourists from all over the world.

\section{Table 12}

Most influential factors to practice the stay inside the hotel.

\begin{tabular}{|l|l|l|l|}
\hline Variable & Frequency* & Percentage (\%) & Rank \\
\hline Alone & 210 & 14.5 & 3 \\
\hline With Family & 496 & 34.2 & 2 \\
\hline With Friends & 592 & 40.8 & 1 \\
\hline $\begin{array}{l}\text { With Co- } \\
\text { Workers }\end{array}$ & 150 & 10.5 & 4 \\
\hline
\end{tabular}

*More than one answer is possible.

Table (12) refers that "With Friends" came in first rank (frq. $=592, \mathrm{P}=40.8 \%$ ), followed by "With Family" (frq. $=496, \mathrm{P}=34.2 \%$ ) and "Alone" (frq. $=210, \mathrm{P}=14.5 \%)$. On the other hand, "With CoWorkers" (frq. $=150, \mathrm{P}=10.5 \%$ ) ranked the last variable. The findings show that tourists visiting Egypt do so with their friends and family, which is a positive indicator of increased spending and the discovery of additional attractions with others.

\section{Table 13}

Most factors that affect hotel choice.

\begin{tabular}{|l|l|l|l|}
\hline Variable & Frequency* & $\begin{array}{l}\text { Percentage } \\
(\%)\end{array}$ & Rank \\
\hline Hotel Location & 356 & 21.8 & 3 \\
\hline Hotel Class & 379 & 23.2 & 2 \\
\hline Prices & 591 & 36.2 & 1 \\
\hline $\begin{array}{l}\text { Marketing } \\
\text { Offers }\end{array}$ & 306 & 18.8 & 4 \\
\hline
\end{tabular}

*More than one answer is possible.

Table (13) refers that, "Prices" came at first rank (Frq. $=591, \mathrm{P}=36.2 \%$ ), followed by "Hotel Class" (Frq. $=379, \mathrm{P}=23.2 \%$ ) and "Hotel Location" (Frq. 
$=356, \mathrm{P}=21.8 \%)$. "Marketing Offers" (Frq. = 306, $\mathrm{P}=18.8 \%$ ) ranked the last variable. This result reflected the important role of prices in influencing travelers' decisions on which hotel to stay in.

\section{Table 14}

the most classes of hotels that participants prefer to stay in Egypt.

\begin{tabular}{|l|l|l|l|}
\hline Variable & Frequency* & Percentage (\%) & Rank \\
\hline $\begin{array}{l}\text { One star } \\
\text { hotels }\end{array}$ & 75 & 7.2 & 5 \\
\hline $\begin{array}{l}\text { Two star } \\
\text { hotels }\end{array}$ & 97 & 9.3 & 4 \\
\hline $\begin{array}{l}\text { Three star } \\
\text { hotels }\end{array}$ & 288 & 27.5 & 2 \\
\hline $\begin{array}{l}\text { Four star } \\
\text { hotels }\end{array}$ & 365 & 34.8 & 1 \\
\hline $\begin{array}{l}\text { Five star } \\
\text { hotels }\end{array}$ & 222 & 21.2 & 3 \\
\hline
\end{tabular}

*More than one answer is possible.

Table (14) refers that, "four star hotels" came at first rank (frq. $=365, \mathrm{P}=34.8 \%$ ), followed by "Three Star Hotels" (frq. $=288, \mathrm{P}=27.5 \%$ ) followed by "Five Star Hotels" (frq. $=222, \mathrm{P}=$ $21.2 \%$ ) and "Two Star Hotels "(frq. $=97, \mathrm{P}=9.3 \%$ ). On the other hand, "One Star Hotels "(frq. $=75, \mathrm{P}=$ $7.2 \%$ ) ranked last variable. From the results, visitors prefer to stay in high hotel class.

\section{Table 15}

Frequently number of visiting the hotels that after the liberalization of the Egyptian pound exchange rate.

\begin{tabular}{|l|l|l|l|}
\hline Variable & Frequency* & Percentage (\%) & Rank \\
\hline
\end{tabular}

\begin{tabular}{|l|l|l|l|}
\hline $1: 3$ Times & 353 & 40.0 & 1 \\
\hline 4-6 Times & 235 & 26.6 & 3 \\
\hline 7: 9 Times & 240 & 27.2 & 2 \\
\hline $\begin{array}{l}\text { More than 9 } \\
\text { Times }\end{array}$ & 55 & 6.2 & 4 \\
\hline
\end{tabular}

Table (15) mentions that "1: 3 Times" came at first rank (Frq. $=353, \mathrm{P}=40.0 \%)$, followed by "6: 9 Times" (Frq. $=240, \mathrm{P}=27.2 \%$ ) and "4-6 Times" (Frq. $=235, \mathrm{P}=26.6 \%$ ). "More than 9 Times" (Frq. $=55, \mathrm{P}=6.2 \%)$ ranked last variable. The repeated visits of most of the study sample point out the appropriateness of the sample to the research variables.

\section{Table16}

Number of nights after the liberalization of the Egyptian pound exchange rate.

\begin{tabular}{|l|l|l|l|}
\hline Variable & Frequency* & $\begin{array}{l}\text { Percentage } \\
(\%)\end{array}$ & Rank \\
\hline $1: 3$ Nights & 264 & 29.9 & 2 \\
\hline $4: 7$ Nights & 326 & 36.9 & 1 \\
\hline
\end{tabular}

\begin{tabular}{|l|l|l|l|}
\hline $8: 10$ Nights & 235 & 26.6 & 3 \\
\hline $\begin{array}{l}\text { More than } \\
10 \text { Nights }\end{array}$ & 58 & 6.6 & 4 \\
\hline
\end{tabular}

Table (16) refers that, "4:7 Nights" came in first rank (Frq. $=326, \mathrm{P}=36.9 \%$ ), followed by "1: 3 Nights" (Frq. $=264, \mathrm{P}=29.9 \%$ ) and "8:10 Nights" (Frq. $=235, \mathrm{P}=26.6 \%$ ). On the other hand, "More than 10 Nights" (Frq. $=58, \mathrm{P}=6.6 \%$ ) ranked as the last variable. The results show that Egyptian tourists, during their tourist trip, spend more than one night in the hotel, and the significant number of tourist nights spent by the guest during his vacation is clearly a promising indicator, according to the findings. This is consisted with the statistics released by the Central Agency for Public Mobilization and Statistics (CAPMAS) and the Central Bank of Egypt between 2016 and 2019 CAMPS that there is significant increase in the number of visitor nights spent in the Egyptian tourist destinations (CAMPS, 2019; CBE, 2019).

\section{Table 17}

the average tourists spending while staying in the hotel after the liberalization of the Egyptian pound exchange rate

\begin{tabular}{|l|l|l|l|}
\hline \multicolumn{1}{|c|}{ Variable } & Frequency* & Percentage (\%) & Rank \\
\hline $\begin{array}{l}\text { Less than } \\
\text { L.E 3000 }\end{array}$ & 279 & 31.6 & 1 \\
\hline $\begin{array}{l}\text { L.E 3001: } \\
\text { L.E 6000 }\end{array}$ & 237 & 26.8 & 2 \\
\hline $\begin{array}{l}\text { L.E 6001: } \\
\text { L.E 9000 }\end{array}$ & 195 & 22.1 & 3 \\
\hline $\begin{array}{l}\text { More than } \\
\text { L.E 9000 }\end{array}$ & 172 & 19.5 & 4 \\
\hline Total & 883 & 100 & \\
\hline
\end{tabular}

Table (17) refers that, "less than 3000 L.E" came at first rank (Frq. $=279, \mathrm{P}=31.6 \%)$, followed by "3001: 6000 L.E" (Frq. $=237, \mathrm{P}=26.8 \%$ ) and "6001: 9000 L.E" (Frq. = 195, P= 22.1\%). "More than 9000L. E" (Frq. $=172, \mathrm{P}=19.5 \%)$ ranked last variable. This result reflected the usual guest spending a fair amount of money during their stay at the hotel.

\section{Table 18}

Tourist's sample assessment of customer spending the exchange rate liberalization of Egyptian pound.

\begin{tabular}{|l|l|l|l|}
\hline The Axis & Mean & $\begin{array}{l}95 \% \text { Confidence } \\
\text { Interval for Mean* }\end{array}$ & Attitude \\
\hline $\begin{array}{l}\text { Customer } \\
\text { Spending }\end{array}$ & 2.50 & $2.43-2.58$ & disagree \\
\hline
\end{tabular}
*95\% Confidence Interval for Mean of the study population =
$\bar{X} \mp t .0 .025,55^{*}$ Std .Error


Table (18) shows that the 95 percent confidence interval for the mean of "Customer Spending" is between 2.43 and 2.58. According to Joshi et al. (2015) and Rady et al. (2021), when the researcher's goal in a Likert scale question is to "integrate" all items to create a "composite" score for an individual rather than a separate analysis of a single variable answered by all individuals, the individual aggregate score (for all items) reveals the following attitudes: If the score was "less than $1.8, "$ it refers to the attitude of "completely disagree", If the score was between "1.8-less than 2.6," it refers to a "disagree" attitude; if the score was between "2.6-less than 3.4," it refers to a "neutral" attitude; if the score was between "3.4less than 4.2," it refers to a "agree" attitude; and finally if the score was between "4.2-5", it refers to a "completely agree" attitude. As a result, the previous result refers to the "disagree" attitude. The 95\% confidence interval for the mean of "length of stay" was between 2.34 as a lower bound and 2.48 as an upper pound that refers to the attitude of "disagree". Customers' spending was assessed during the Egyptian pound's exchange rate liberalization, and the previous results suggested

\section{Table 19}

Statistics for the customer spending

\begin{tabular}{|l|l|l|l|l|}
\hline Statements & M & SD & Rank & Attitude \\
\hline $\begin{array}{l}\text { 1- My Average spending on travel to tourist areas in Egypt after liberalizing the } \\
\text { Egyptian pound exchange rate at the same level. }\end{array}$ & 2.46 & 1.436 & 6 & disagree \\
\hline $\begin{array}{l}\text { 2- I see that liberalizing the Egyptian pound exchange rate has a positive effect on } \\
\text { my spending on the type of reservation (breakfast only - breakfast and dinner - full } \\
\text { board - all-inclusive - room only) for the hotel. }\end{array}$ & 2.59 & 1.310 & 4 & disagree \\
\hline $\begin{array}{l}\text { 3- The liberalization of the Egyptian pound exchange rate has a positive effect on } \\
\text { my spending on food purchases from restaurants during my stay at the hotel. }\end{array}$ & 2.62 & 1.287 & 1 & disagree \\
\hline $\begin{array}{l}\text { 4- The liberalization of the Egyptian pound exchange rate has a positive effect on } \\
\text { my spending on (alcoholic - soft) drinks during my stay at the hotel. }\end{array}$ & 2.44 & 1.246 & 7 & disagree \\
\hline $\begin{array}{l}\text { 5- My spending on services provided in Egyptian hotels (washing and ironing - } \\
\text { communications) has not been affected negatively by the liberalization of the } \\
\text { Egyptian pound exchange rate. }\end{array}$ & 2.60 & 1.255 & 3 & disagree \\
\hline $\begin{array}{l}\text { 6- From my point of view, my spending on entertainment services (tickets to } \\
\text { theaters, circuses, concerts, gymnasiums and health club) inside the hotel was not } \\
\text { negatively affected by the liberalization of the Egyptian pound exchange rate. }\end{array}$ & 2.61 & 1.300 & 2 & disagree \\
\hline $\begin{array}{l}\text { 7- My spending on tour services (tickets for all types of transportation and ordering } \\
\text { cars) inside the hotel was not affected negatively by the liberalization of the } \\
\text { Egyptian pound exchange rate. }\end{array}$ & 2.25 & 1.383 & 8 & disagree \\
\hline $\begin{array}{l}\text { 8- My spending on shopping services and the purchase of products inside the hotel } \\
\text { (bazaars and shops) was not affected negatively by the liberalization of the } \\
\text { Egyptian pound exchange rate. }\end{array}$ & 2.48 & 1.339 & 5 & disagree \\
\hline $\begin{array}{l}\text { Overall mean } \\
\text { M - Mean SD Stangang }\end{array}$ & 2.50 & 1.148 & & \\
\hline
\end{tabular}

$\mathrm{M}=$ Mean $\mathrm{SD}=$ Standard Deviation negative effect of exchange rate liberalization on the Egyptian customers spending. this is consisted with El-Badawy (2017), because of the high prices of imported goods, which lead to the high cost of production and services, the exchange rate push towards imposing new taxes that affects the prices and the purchasing power for the domestic tourists and a consequence of the high price of tourism programs led to a clear decline in the number of travelers with the slowdown in tourism activity Moreover, fluctuations in the exchange rate indicate risks to tourist destinations, causing tourists to be hesitant to visit or cancel their trips to the area affected the prices of goods, services, and tourism products and reflect in a decrease in the purchasing power of Egyptian tourists (Anter and El-Nagy, 2018).

\subsection{Customer Spending Statistics}

The variable aimed to assess customer spending during the Egyptian pound's exchange rate liberalization during their travel to Egypt. Table (12) shows the information collected: 
According to table (19), the most effective variables were "The liberalization of the Egyptian pound exchange rate has a positive effect on my spending on food purchases from restaurants during my stay at the hotel". $(\mathrm{M}=2.62, \mathrm{SD}=1.287)$, "From my point of view, my spending on entertainment services (tickets to theaters, circuses, concerts, gymnasiums and health club) inside the hotel was not negatively affected by the liberalization of the Egyptian pound exchange rate." ( $\mathrm{M}=2.61, \mathrm{SD}=1.300)$ and " My spending on services provided in Egyptian hotels (washing and ironing - communications) has not been affected negatively by the liberalization of the Egyptian pound exchange rate." $(\mathrm{M}=2.60, \mathrm{SD}=1.255)$. The least effective variables were "I see that liberalizing the Egyptian pound exchange rate has a positive effect on my spending on the type of reservation (breakfast only - breakfast and dinner full board - all-inclusive - room only) for the hotel." $(\mathrm{M}=2.59, \mathrm{SD}=1.310)$, "My spending on shopping services and the purchase of products inside the hotel (bazaars and shops) was not affected negatively by the liberalization of the Egyptian pound exchange rate." $(\mathrm{M}=2.48, \mathrm{SD}=1.310)$, and "My Average spending on travel to tourist areas in Egypt after liberalizing the Egyptian pound exchange rate at the same level." (M=2.46, $\mathrm{SD}=1.436$ ), "The liberalization of the Egyptian pound exchange rate has a positive effect on my spending on (alcoholic - soft) drinks during my stay at the hotel." $(\mathrm{M}=2.44, \mathrm{SD}=1.246)$, and "My spending on tour services (tickets for all types of transportation and ordering cars) inside the hotel was not affected negatively by the liberalization of the Egyptian pound exchange rate." ( $M=2.25$, $\mathrm{SD}=1.383$ ). As well, the overall mean of the above variables was $(2.50)$ with a standard deviation of (1.148). This result indicated that liberalizing the exchange rate has a noticeable impact on hotel customer spending. The results indicate that the liberalization of the exchange rate has a negative impact on the spending of Egyptian tourists, especially on recreational services, such as buying tickets for concerts and theaters during their stay in the hotel, and also that their average spending during their stay is no longer the same. Furthermore, the liberalization of the Egyptian pound exchange rate has had a negative impact on Egyptian tourists' spending on alcoholic beverages and food. Whereas the exchange rate liberalization had a significant impact on the type of accommodation that Egyptian tourists desired, in addition to its negative impact on airline tickets and other modes of transportation, as well as other services provided in hotels, such as communication services, laundry, and ironing, and there was also an impact on spending on buying gifts, souvenirs, and other products. This consisted with El-Sherbini (2018) that Egypt's exchange rate strategy considerably impacts the Egypt's domestic prices and the cost of living for Egyptian tourists who pay in Egyptian pound for services and products. Furthermore, Ibrahim and Bashir (2021) stated that the depreciation of the Egyptian pound influenced the prices of goods, services, and tourism and hotel products which increased, that have little impact on the two sectors because the money generated by tourists and hotel services will be in dollars, increasing the value of revenues but increasing the cost of products and raw materials (Soliman and Shedeed, 2018).

\subsection{Test of Hypothesis}

To test $\mathrm{H} 1$ of the research, the Pearson correlation was used to determine whether there is a significant correlation between the expected and observed values of one or more variables (West, 2008).

Table 20

Statistically Significant Correlation between the Tourist's Customer Spending and Length of Stay

\begin{tabular}{|l|l|c|c|}
\hline \multicolumn{2}{|c|}{} & $\begin{array}{l}\text { Customer } \\
\text { Spending }\end{array}$ & $\begin{array}{l}\text { Length of } \\
\text { Stay }\end{array}$ \\
\hline $\begin{array}{l}\text { Customer } \\
\text { Spending }\end{array}$ & $\begin{array}{l}\text { Pearson } \\
\text { Correlation }\end{array}$ & 1 & $.895^{* *}$ \\
\cline { 2 - 4 } & Sig. (2-tailed) & & .000 \\
\cline { 2 - 4 } & $\mathrm{N}$ & 539 & 539 \\
\hline \multirow{2}{*}{$\begin{array}{l}\text { Length of } \\
\text { Stay }\end{array}$} & $\begin{array}{l}\text { Pearson } \\
\text { Correlation }\end{array}$ & $.895^{* *}$ & 1 \\
\cline { 2 - 4 } & Sig. (2-tailed) & .000 & \\
\cline { 2 - 4 } & $\mathrm{N}$ & 539 & 539 \\
\hline \multirow{2}{*}{$\begin{array}{l}* * \text { Correlation is significant at the } 0.01 \\
\text { level (2-tailed). }\end{array}$}
\end{tabular}

Table (20) illustrates that there is a positive and significant relationship between customer spending and Length of stay. The value of spearman correlation coefficient is $\left(895^{* *}-\operatorname{sig}=0.000\right)$. This proves the incorrectness of hypothesis (1). These results identify that there is a strong positive relation between relationship between customer spending and Length of stay. These results identify that there is a strong positive relation between the customer spending and Length of stay, the more Length of stay the more customer spending. This is consistent with Soler et al. (2018) and Park et al. 
(2020) where they indicated that the length of stay in a tourist destination has a significant impact on customer spending and has a positive effect on total customer spending, and there is a positive correlation between the length of stay in the host country and an increase in local sales, as the length of stay is one of the most important determinants. To examine $\mathrm{H} 2$ of the research, the Mann-Whitney test was used to examine $\mathrm{H}_{2}$ of the study; MannWhitney is a test that is used to compare two independent samples that are not regularly distributed groups (Nashar, 2008). The MannWhitney test provided the following results:

\section{Table 21}

Differences between Egyptian and foreign tourists in terms of customer spending

\begin{tabular}{|l|l|l|l|l|}
\hline & Nationality & $\begin{array}{l}\text { No. of } \\
\text { customers }\end{array}$ & $\begin{array}{l}\text { Mean } \\
\text { Rank }\end{array}$ & Sig. \\
\hline \multirow{2}{*}{$\begin{array}{l}\text { Customer } \\
\text { Spending }\end{array}$} & Egyptian & 539 & 347.86 & \multirow{2}{*}{000} \\
\cline { 2 - 4 } & foreigner & 344 & 589.50 & \\
\cline { 2 - 4 } & Total & 883 & & \\
\hline
\end{tabular}

Table (21) shows that the values of Sig are less than the level of significance $(0.05)$, which means that there are significant differences between Egyptians and foreigners concerning customer spending under the liberalization of the exchange rate. This result coincided with the fact that the study's second hypothesis was rejected. There are significant differences between Egyptian and foreign tourists in terms of customer spending. This is consistent with the findings of Zhang et al. (2018) and Gavurova et al. (2020) who found that subcultures like nationality have a direct impact on customer spending. As well, this difference is usually due to the differences between foreign and

\section{Table 23}

Differences between the age categories concerning customer spending in hotels under the liberalization of the exchange rate

\begin{tabular}{|c|c|c|c|c|c|}
\hline & Age & No. of customers & Mean Rank & Chi-Square & Sig. \\
\hline \multirow{5}{*}{$\begin{array}{l}\text { Customer } \\
\text { Spending }\end{array}$} & 16: 25 years old & 209 & 381.21 & \multirow[t]{5}{*}{29.945} & \multirow[t]{5}{*}{.000} \\
\hline & 26: 35 years old & 256 & 414.15 & & \\
\hline & 36: 45 years old & 260 & 485.75 & & \\
\hline & More than 46 years old & 158 & 495.54 & & \\
\hline & Total & 883 & & & \\
\hline
\end{tabular}

The Kruskal-Wallis test's null hypothesis is that the samples' mean rankings are the same (McDonald, 2014). According to the table (23), the Sig. value in the previous table is $(0.000)$, showing that there are significant differences in customer spending between the four age categories. As a result of this finding, hypothesis four of the study was unacceptable, meaning that there are statistical domestic tourists regarding distances, whereas the foreign tourist is likely to travel for a longer period to pay for the high travel costs, while the local tourist prefers to take shorter trips (Thrane, 2016). To examine $\mathrm{H} 3$ of the research, the Mann-Whitney test provided the following results:

\section{Table 22}

Differences between males and females concerning customer spending in hotels under the liberalization of the exchange rate.

\begin{tabular}{|l|l|l|l|l|}
\hline & Gender & $\begin{array}{l}\text { No. of } \\
\text { customers }\end{array}$ & $\begin{array}{l}\text { Mean } \\
\text { Rank }\end{array}$ & Sig. \\
\hline $\begin{array}{l}\text { Customer } \\
\text { Spending }\end{array}$ & Male & 441 & 494.89 & \multirow{2}{*}{.000} \\
\cline { 2 - 4 } & Female & 442 & 389.23 & \\
\cline { 2 - 4 } & Total & 883 & & \\
\hline
\end{tabular}

Table (22) clears that the significance value was (0.000), showing that there are significant differences in customer spending between males and females. As a result of this finding, the study's third hypothesis was unacceptable. There are significant differences between males and females regarding the spending level in hotels under the liberalization of the exchange rate. Hence, according to Ramya and Ali (2016), customers' gender affects their spending power, where male tourists spend more than females.

To test the $\mathrm{H} 4$ of the research, The Kruskal-Wallis test was used when an individual has one scale factor and one nominal factor. The Kruskal-Wallis test is used to see if the mean ranks are similar across all samples, also used when the data distribution of study variables does not meet the normality requirements (McDonald, 2014). The following result from the Kruskal-Wallis test: differences between the age categories regarding spending on hotels under the exchange rate liberalization. This is consistent with Luo (2019) that there is a significant impact of age on customer spending and that impact varies between older and younger travelers.

To test the H5 of the research, the following are the results of the Kruskal-Wallis test: 


\section{Table 24}

Differences between the Income Categories Concerning Customer Spending In Hotels under the Liberalization of the Exchange Rate

\begin{tabular}{|l|l|l|l|l|l|}
\hline & $\begin{array}{l}\text { Income level (monthly in } \\
\text { Egyptian pound) }\end{array}$ & No. of customers & Mean Rank & Chi-Square & Sig. \\
\hline \multirow{3}{*}{$\begin{array}{l}\text { Customer } \\
\text { Spending }\end{array}$} & Less Than L.E 4000 & 199 & 404.76 & & \\
\cline { 2 - 4 } & From L.E 4001:8000 & 154 & 300.39 & \multirow{3}{*}{78.566} & \multirow{3}{*}{.000} \\
\cline { 2 - 4 } & From L.E 8001: 12000 & 221 & 510.40 & \\
\cline { 2 - 4 } & More Than L.E 12000 & 309 & 487.64 & \\
\cline { 2 - 4 } & Total & 883 & & \\
\hline
\end{tabular}

From the previous table, it is obvious that Sig. value is $(0.000)$, so there are significant differences between the income categories regarding spending on hotels under the liberalization of the exchange rate. Because of this finding, hypothesis six of the study was unacceptable. There are significant differences between the income categories regarding spending on hotels under the exchange rate liberalization. These findings indicate that tourists with a high- income level "From L.E 8001 to L.E 12000 " tend to spend more, which is consistent with Luo (2019) and Ortega and Osbat (2020) finding that when a customer's income increases, so do travel demand, and customers with high income spend more than those with low income. Furthermore, income expectation is one of the important determinants of customer buying behavior. If he expects an increase in his income, he will spend more on goods and services.

Results and Discussion of the Interviews with the Hotels Managers and Tourism Economists

Letters from (11) managers of hotels and tourism economists in Hurghada, Marsa Alam, Safaga, and Luxor. Based upon the structured interviews conducted with the 11 managers of hotels and tourism economists, collected data was transcribed and set for analysis, and a content analysis technique was adopted to analyze the collected data. The following comments are obtained:

1. To what extent, do you see the liberalization of the exchange rate affect the costs inside the hotels?

"The decision to liberalize the exchange rate led to an increase in the costs of raw materials inside the hotels used in the food and beverage sector, also caused an increase in the costs of repair and maintenance of equipment and devices, as well as the high costs of equipment and construction for tourist hotels ".

Added "The exchange rate led to an increase in fuel costs, which led to an increase in the value of airline tickets and transportation as well as increased marketing costs and services provided by hotels".

"The negative effects of liberalizing the exchange rate continued, with some hotels reducing permanent employees and hiring temporary. Also, due to the low wages as a result of the depreciation of the Egyptian pound many workers leave their work".

2. Is there a positive effect of liberalizing the exchange rate on tourists' spending during their stay in hotels?

"The Egyptian tourist destination became the cheapest compared to other international destinations and there was a negative effect of the decline of the Egyptian pound value facing other currencies on the flow of the international tourists to Egypt as it attracted a low-income segment, also reduced the level of expenditure ".

Added "... Probably, the increase of the Egyptian pound exchange rate value could attract the segment of the high-income tourism market."

3. Please, can you add any suggestions to develop the level of tourism in Egypt?

"Ministry of tourism should prevent the illegal agencies from selling optional tours and close these agencies, Work to develop all services that work to achieve the highest degree of customer satisfaction and make offers to encourage tourism".

"Existence of complete tourism programs for the various tourist regions of Egypt at low competitive prices to encourage tourism and domestic and family travel in particular in light of the state of the tourist recession and the circumstances surrounding us, and for future generations to know the beauty of the regions of our beloved country from the antiquities and ancient civilization and the beauty of the picturesque nature and the excellent atmosphere of Egypt 
The results of the interviews can be summarized in the following points:

- The decision to liberalize the exchange rate led to an increase in the costs (raw materials, fuel costs, repair and maintenance of equipment) and this led to an increase in the value of airline tickets and transportation, as well as increased marketing costs and services provided by hotels.

- The increase of Egyptian pound exchange rate value negatively reduced the level of expenditure

- Existence of complete tourism programs for the various tourist regions of Egypt at low competitive prices to encourage domestic tourism and family travel.

\section{Conclusion and Recommendation}

The research indicates several results to measure the impact of the liberalization of the exchange rate on the spending of guests and the length of stay in Egyptian hotels in the cities investigated. The conclusion points can be shown in the following.

1. There is a statistically significant effect of the exchange rate liberalization on the spending of Egyptian guests in hotels, as there is a negative impact of the exchange rate liberalization that has led to a decrease in the level of spending of Egyptian tourists because of the depreciation of the Egyptian pound against the dollar.

2. There is a strong positive relationship between customer spending and length of stay, the more length of stay the customer spending.

3. There are significant differences between Egyptians and foreign tourists in terms of customer spending and length of stay under the liberalization of the exchange rate, as foreigners spend more money and stay longer than Egyptians.

4. There are significant differences between males and females concerning the spending level in hotels under the liberalization of the exchange rate, as male tourists spend at a higher rate than females.

5. There is a significant difference between the age categories concerning spending in hotels under the exchange rate liberalization. Whereas, tourists aged between 36:45 years old spend more than tourists of other ages.
6. There is significant difference between the marital statuses concerning the length of stay in hotels under the exchange rate liberalization. As married tourists spend more nights followed by single tourists.

7. There are significant differences between the income categories concerning spending in hotels under the exchange rate liberalization. This indicating that tourists with a highincome level "From L.E 8001: L.E 12000 " tend to spend more.

8. The increased value of the Egyptian pound has a detrimental impact on hotel services due to low quality and a lack of program diversification.

9. The decision to liberalize the exchange rate raised costs (raw materials, fuel expenses, equipment repair, and maintenance), increasing the value of airline tickets and transportation and entertainment services and hotel products due to pricing changes.

A series of recommendations may be identified based on the literature and findings of the study to maximize the benefits of liberalizing the Egyptian pound's exchange rate in the tourism and hotel sectors, as well as identify ways to mitigate the negative consequences of this choice. Such as:

1. Imposing mandatory prices on tourism goods and services and establishing a profit margin for those who trade these goods and services by regulating the prices of tourism goods and services in Egypt, it is possible to keep the country's cheap prices under control. As a result, avoid charging the guest more than the stipulated rates and provide services to the guest at these rates.

2. Activating the government's role in eradicating the black market, emphasizing the central bank's role in assisting tourism and hotel projects, and the need to coordinate all foreign currency deposit and transfer transactions related to the tourism and hotel sectors through a specific Egyptian government bank to prevent the currency from being diverted into the parallel market. Moreover, make every effort to encourage local production to accomplish product selfsufficiency.

3. Controlling the exchange market requires the Central Bank's participation by offering new batches of dollars into the market to overcome 
the black market, which leads to the dollar's depreciation.

4. Maintaining the foreign exchange market requires a balanced supply-demand ratio and an increase in exports and a decrease in imports by expanding the supply of the dollar, including limiting imports and promoting exports, as well as considering changes for Egyptians to withdraw dollars from abroad by issuing travel and work permits in the dollar.

5. The necessity of stopping the payment of dues inside Egypt in dollars, in addition to rationalizing the import bill, which is made in dollars, stressing that this matter requires the cooperation of the ministries of industry and finance with the Central Bank.

6. Changes in Egyptian pound exchange rates did not affect the older segment's reliance on the sector. To attract this market, it must develop programs that cater to their demands and address the most popular types of tourism, such as green tourism and cultural tourism.

7. Assisting tourist firms in broadening their offerings and attempting to attract new segments.

This research contributes to the knowledge of the effects resulting from the liberalization of the exchange rate of the Egyptian pound on the Egyptian hotel sector, especially the spending of customers and the period of stay. It also provides a set of important recommendations through which it is possible to overcome the negative effects on the tourism sector in Egypt and help increase foreign income.

Future research has to focus on the effect of exchange rate liberalization on the wages and salary of workers in the tourism and hotel sector. Moreover, it should also focus on the relationship between the liberalization of the exchange rate and the quality of food and beverages provided inside the hotels.

\section{References}

Aalen, P., Iversen, E. K., and Jakobsen, E. W. (2019). Exchange Rate Fluctuations and Demand for Hotel Accommodation: Panel Data Evidence from Norway. Scandinavian Journal of Hospitality and Tourism, 19(2), 210-225.

Abdelgany, M. (2020). Determinants of Real Exchange Rate Evidence: from Egypt. Journal of Politics and Economics, 7 (Issue (6) April 2020), 1-22.

Aditi, B. (2019). The Effect of Services, Price Discount and Brand Equity on Consumer Purchase Decisions in Go-Jek A Technology Start-up Transport.
Academic Journal of Economic Studies, 5 (2), Pp. 21-31.

Alstadheim, R., Bjørnland, H. C., and Maih, J. (2021). Do central banks respond to exchange rate movements? A Markov-switching structural investigation of commodity exporters and importers. Energy Economics, 96, 105138.

Amador, M., Bianchi, J., Bocola, L., and Perri, F. (2020). Exchange rate policies at the zero lower bound. The Review of Economic Studies, 87(4), 1605-1645.

Andari, R., Abdullah, T., and Aulia, D. (2019, June). The Effect of Customer Ethnocentrism on Tourists' Purchase Decision. In 3rd International Seminar on Tourism (ISOT 2018).

Anter, M., and El-Nagy, S. (2018). The Effect of the Egyptian Pound Exchange Rate Change on the International Tourist Demand to Egypt. International Journal of Heritage, Tourism and Hospitality, 12(2), 160-181.

Central Agency for Public Mobilization and Statistics (CAPMAS). (2019). Tourism in Figures, Arab Republic of Egypt.

Central Bank of Egypt. (2003). Annual report. Retrieved from https://www. cbe.org.eg/en/EconomicResearch/Publications/Pag es/AnnualReport.aspx.

Central Bank of Egypt. (2010). Annual report. Retrieved from https://www. cbe.org.eg/en/EconomicResearch/Publications/Pag es/AnnualReport.aspx.

Central Bank of Egypt. (2016). Annual report. Retrieved from https://www. cbe.org.eg/en/EconomicResearch/Publications/Pag es/AnnualReport.aspx.

Central Bank of Egypt. (2019). Annual report. Retrieved from https://www. cbe.org.eg/en/EconomicResearch/Publications/Pag es/AnnualReport.aspx.

Central Bank of Egypt. (2020). Annual report. Retrieved from https://www. cbe.org.eg/en/EconomicResearch/Publications/Pag es/AnnualReport.aspx.

Dorota, R. H. (2013). Determinants of consumer purchasing Behaviour/Uwarunkowania zachowań nabywczych konsumentów w świetle teorii zachowań konsumentów. Management, 17(1), 333345.

Egyptian Tourism Authority. (2020). Retrieved from http:// Egypt. Travel regions.

El-Badawy, A. (2017). The effect of foreign direct investment and economic liberalization policy on the growth rate of the gross domestic product in Sudan (1985-2010). The Red Sea University Journal for the Humanities, 4.

El-Bagouri, K.A. (2016). The effect of the differences in the Egyptian pound exchange rates on the economy. 
Retrieved from https://qcc.org.sa/qcc_files/drs_tthyr_lfrwq_fy_sr_srf_ljnyh_lmsry.

El-Gazar, H.A. (2018). Evaluating the Egyptian monetary policies since 2003 with a special interest in their role in supporting the goals of development plans. Planning and Development Issues Series No. 297- National Planning Institute, No. 8.

El-Sherbini, A. R. (2018). Towards an effective management of Egypt's international reserves. National Planning Institute Policy Handbook Series, Issue 8.

Retrieved

from http://repository.inp.edu.eg/xmlui/handle/1234567 89/4548

Ezzahid, E., and Maouhoub, B. (2020). Real effective exchange rate dynamics in Morocco: Exploring Balassa-Samuelson effect under capital account liberalization. Journal of International Studies, 13(1).

Gavurova, B., Suhanyi, L., and Rigelský, M. (2020). Tourist spending and productivity of economy in OECD countries-research on perspectives of sustainable tourism. Entrepreneurship and Sustainability Issues.

Gómez, P. G., Sanz, M. D. M. Z., and Sanz, A. I. Z. (2019). Modelling the Choice of Tourism Accommodation in Spain. In 9th Advances In Hospitality and Tourism Marketing and Management Conference Proceedings (P. 439).

Hair, A., Black, B., T. (2009), "Multivariate Data Analyses", 7th edition.

He, Q., Liu, J., and Zhang, C. (2021). Exchange rate exposure and its determinants in China. China Economic Review, 65, 101579.

Hou, H., and Wu, H. (2021). Tourists' perceptions of green building design and their intention of staying in green hotel. Tourism and Hospitality Res., 21(1), 115-128.

Ibrahim, A. A. A., and Bashir, M. S. (2021). The Effect of Real Exchange Rate Changes on External Trade Balance in Sudan: Testing J-Curve Hypothesis. Nile Journal of Business and Economics, 6(16), 3-23.

International Monetary Fund. (2005). Country Report no. 06/253, Arab Republic of Egypt: 2006 Article IV Consultation, July 2006, p. 3. Retrieved from https://www.imf.org/external/pubs/ft/scr/2006/cr06 253.pdf.

International Monetary Fund. (2018). SDR valuation, accessed on 17 January2020. Retrieved from https://www.imf.org/external/np/fin/data/rms sdrv .aspx

International Monetary Fund. (2019). SDR valuation, accessed on 17 January2020. Retrieved from https://www.imf.org/external/np/fin/data/rms_sdrv aspx

International Monetary Fund. (2020). SDR valuation, accessed on 17 January 2020. Retrieved from https://www.imf.org/external/np/fin/data/rms_sdrv aspx

Irungu, J. K. (2015). Effect of Exchange Rate Fluctuations on Market Capitalization at the Nairobi Securities Exchange. (Doctoral dissertation, University of Nairobi).

Joshi, A., Kale, S., Chandel, S. and Pal, D., (2015), " Likert Scale: Explored and Explained", British Journal of Applied Science

Kapoor, S., and Kumar, N. (2019). Does Packaging Influence Purchase Decisions Of Food Products? A Study of Young Customers of India. Academy Of Marketing Studies Journal, 23(3).

Khalaf, M. A. R., Elias, W., and Wafik, G. M. (2020). Evaluating the Optional Tours Service Quality and its Effect on Tourist's Satisfaction in Marsa Alam City. Minia Journal of Tourism and Hospitality Research MJTHR, 10(1), 51-80. 110.

Liu, Z., Wang, P., and Xu, Z. (2021). Interest Rate Liberalization and Capital Misallocations. American Economic Journal: Macroeconomics, 13.

Luo, L. (2019). Temporal Modelling of Customer Behaviour. Springer. ISBN 978-3-030-18288-5 ISBN 978-3-030-18289-2 (E-book). Https://Doi.Org/10.1007/978-3-

Masoomzadeh, s., and Lamsso, m. S. (2017) study of impact of exchange rate on tourism balance of payment in countries with top tourist attractions (vector error correction approach).

Massidda, C., Piras, R., and Seetaram, N. (2020). Analysis of British Travellors' Tourism Expenditure. Annals of Tourism Research.

Mazzarol, T., and Reboud, S. (2020). Creating Customers. In Small Business Management (Pp. 153-192). Springer, Singapore.

McDonald, J., (2014). Kruskal-Wallis test. Handbook of Biological Statistics, 3rd Ed., Sparky House Publishing, Baltimore, Maryland.

Mishra, R., Singh, R. K., and Koles, B. (2021). Consumer Decision-Making in Omnichannel Retailing: Literature Review and Future Research Agenda. International Journal of Consumer Studies, 45(2), 147-174.

Mokhtar, M. R., and Shamsudin, M. F. (2020). How to keep up with customer? Journal of Postgraduate Current Business Research, 5(1).

Nashar, N., (2008). The Mann-Whitney U: A Test Assessing Whether Two Independent Samples Come from the Same Distribution. Tutorials in Quantitative Methods for Psychology, 4(1).

Njoya, E. T. (2020). An analysis of the tourism and wider economic impacts of price-reducing reforms in air transport services in Egypt. Research in Transportation Economics, 79, 100795.

Oluwatayo, J. A. (2012). Validity and reliability issues in educational research. Journal of educational and social research, 2(2), 391-391. 
Ortega, E., and Osbat, C. (2020). Exchange rate passthrough in the euro area and EU countries. Banco de Espana Occasional Paper, (2016).

Park, S., Woo, M., and Nicolau, J. L. (2020). Determinant factors of tourist expenses. Journal of Travel Research, 59(2), 267-280.

Peak, C. (2016). Discovering the Relationship between Macroeconomic Trends and Regional Theme Park Performance (Doctoral dissertation, Northcentral Uiv).

Putra, E. (2019). The Influence of Promotion and Brand Image toward Purchase Decision of Honda Vario. Jurnal Apresiasi Ekonomi, 7(1), 121-130.

Rady, A., Sotohy, H., and Ammar, S. A. (2021). Employment of the Ancient Egyptian Feast Foods in Egyptian Hotel Menus and Its Impact on Promoting Food Tourism. Journal of Association of Arab Universities for Tourism and Hospitality.

Ramya, N., and Ali, M. (2016). Factors Affecting Consumer Buying Behavior. International Journal of Applied Research, 2(10), 76-80.

Red Sea Governorate. (2020). Retrieved from http://www.redsea.gov.eg/touris

Smolcic Jurdana, D., and Soldic Frleta, D. (2017). Satisfaction as a determinant of tourist expenditure. Current Issues in Tourism, 20(7), 691704

Soler, I. P., Gemar, G., and Correia, M. B. (2018). Length of Stay for Tourists' Inland Trips. Journal of Destination Marketing and Management, 10, 4960 .
Soliman, M., and Shedeed, M. (2018). The effect of liberalizing the exchange rate on the economies of the tourism and hotel industries in Egypt. International Journal of Heritage, Tourism and Hospitality - Faculty of Tourism and Hotels Fayoum University, V. (12) - I. (1/2).

Thompson, S. K. (2012). Sampling, Third Edition, p: 59-60

Thrane, C. (2016). Students' Summer Tourism: Determinants of Length of Stay (Los). Tourism Management, 54, 178-184.

West, J., (2008). Use of the Chi-Square Statistic. Johns Hopkins Bloomberg School of Publication, Johns Hopkins University

Weston, S. J., Gladstone, J. J., Graham, E. K., Mroczek, D. K., and Condon, D. M. (2019). Who Are The Scrooges? Personality Predictors of Holiday Spending. Social Psychological and Personality Science, 10(6), 775-782.

Yu, M. (2021). Exchange Rate Movements and Exporter Profitability. In Exchange Rate, Credit Constraints and China's International Trade (pp. 137-161). Palgrave Macmillan, Singapore.

Yung, J. (2021). Can interest rate factors explain exchange rate fluctuations. Journal of Empirical Finance, 61, 34-56. https://doi.org/10.1016/j.jempfin.2021.01.005

Zhang, T. C., Jahromi, M. F., and Kizildag, M. (2018). Value Co-Creation in a Sharing Economy: The End of Price Wars? International Journal of Hospitality Management, 71, 51-58. 